\title{
Doe/mc/31175 -.8
}

\section{Treatment of Metal-Laden Hazardous Wastes with Advanced Clean Coal Technology By-Products}

\author{
Quarterly Report \\ June 30 - September 30, 1996
}

By

James T. Cobb; Ronald D. Neufeld

Jean R. Blachere; Emanuel M. Schreiber

B. Vourneen Clifford; Jesse Pritts

Jana Agostini; Sarah Spencer

Guansheng Yin; Carl F. Bender

Work Performed Under Contract No.: DE-FC21-94MC31175

For

U.S. Department of Energy

Office of Fossil Energy

Federal Energy Technology Center

P.O. Box 880

Morgantown, West Virginia 26507-0880

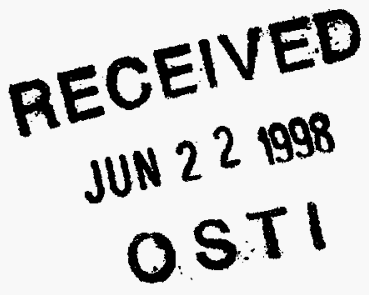

By

University of Pittsburgh

350 Thackeray Hall

Pittsburgh, Pennsylvania 15260

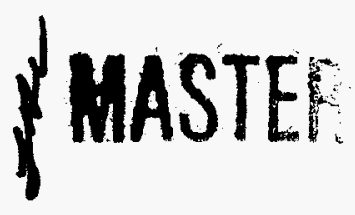

DISTAIBUTION OF THIS DOCUMENT IS UNLIMITEO 


\section{Disclaimer}

This report was prepared as an account of work sponsored by an agency of the United States Government. Neither the United States Government nor any agency thereof, nor any of their employees, makes any warranty, express or implied, or assumes any legal liability or responsibility for the accuracy, completeness, or usefulness of any information, apparatus, product, or process disclosed, or represents that its use would not infringe privately owned rights. Reference herein to any specific commercial product, process, or service by trade name, trademark, manufacturer, or otherwise does not necessarily constitute or imply its endorsement, recommendation, or favoring by the United States Government or any agency thereof. The views and opinions of authors expressed herein do not necessarily state or reflect those of the United States Government or any agency thereof. 


\section{DISCLAIMER}

Portions of this document may be illegible electronic image products. Images are produced from the best available original document. 


\section{TABLE OF CONTENTS}

$\begin{array}{lc}\text { Executive Summary } & 1\end{array}$

$\begin{array}{ll}\text { Introduction } & 3\end{array}$

Laboratory and Field Work $\quad 4$

$\begin{array}{lr}\text { Reports and Presentations } & 9\end{array}$

$\begin{array}{lr}\text { Outside Contacts } & 10\end{array}$

$\begin{array}{lr}\text { Administrative Aspects } & 12\end{array}$

$\begin{array}{lr}\text { Plans for the Next Quarter } & 15\end{array}$

Appendix A - Treatment of Sandblast Waste with By-Products from Clean Coal 16 Technologies

Appendix B - Overview of Permeability Studies on Concrete Cylinders 25

Appendix C - A Study of Optimizing the Recipes for Stabilization of Metal-Laden 31 Waste/By-Product Mixtures

Appendix D - Exchange of Letters between Envirite Corporation, and the University 48 of Pittsburgh on Phase 2

Appendix E - Program for the Research Experience for Undergraduates Summer Research Symposium 


\section{EXECUTIVE SUMMARY}

During the fourth quarter of Phase 2, work continued on evaluating treatment of the seventh residue of Phase 1, conducting scholarly work, preparing for field work, preparing and delivering presentations, and making additional outside contacts.

\section{Laboratory Analyses}

Solidification studies on the seventh waste, the sandblast residue, were conducted on the successful stabilization recipes of the 30\% dosage of CONSOL by-product and the $50 \%$ dosage of the Tidd by-product found during the last quarter. The product of treatment with the CONSOL by-product exhibited no unconfined compressive strength. That with the Tidd byproduct yielded very modest strength. Good stabilization accompanied the solidification with the CONSOL by-product but the (aged) Tidd by-product failed to stabilize the solidified sandblast residue.

\section{Scholarly Work}

The two graduate students assigned to this project have both continued their work toward preparing their theses during the quarter. One student initiated evaluations of the solidified sandblast residue using $x$-ray diffraction and the scanning electron microscope. The other examined the long-term stabilization of the solidification samples prepared a year ago. A general trend toward destabilization was found.

Two undergraduate students and a research associate made interesting contributions to the project. One undergraduate assisted one of the graduate students in the TCLP and ASTM leachate evaluation of the solidified sandblast residues. $J$ The other investigated the possibility of permeability studies. The research associate evaluated the stabilization recipes of the project, based upon his experience in by-product utilization in China.

\section{Preparation for Field Work}

The withdrawal of Mill Service, Inc. (MSI) led to a search for a new subcontractor. The Canton, Ohio plant of Envirite Corporation, was approached, but they declined the invitation. As the quarter ended, two other candidates, EO Company and Heritage Environmental Services, Inc., were considering invitations.

\section{Reports and Presentations}

The paper entitled "Hazardous Waste Stabilization with Clean-Coal Technology Ash Residuals," which was presented at the 18th Biennial IAWO Conference in Singapore was accepted for publication in Water Science and Technology. 
The undergraduate, who assisted in the TCLP and ASTM leachate evaluations of the solidified sandblast residue, gave a fifteen-minute presentation on her work to the Research Experience for Undergraduate Summer Research Symposium on August 7, 1996.

\section{Outside Contacts}

On July 19, 1996 the principal investigator attended the meeting in Annapolis, Maryland of the E50.03 subcommittee of the American Society for Testing and Materials.

Two discussions were held with Dravo Lime Company of Pittsburgh, Pennsylvania concerning the utilization of coal combustion by-products (CCBs) in China.

A discussion was held on September 27, 1996 with West Virginia University concerning autoclaved cellular concrete using CCBs.

\section{Plans for the Next Quarter}

During the quarter from September 30 through December 30, 1996, work will continue on Tasks 4 and 5 of Phase 1.

Work on Task 1 of Phase 2 will continue. Because of the delay in initiating the commercial tests of Phase 2, caused by the withdrawal of MSI from Phase 2 and the extended search for a new subcontractor, the project team has invoked a one-year no-cost extension to the contract to September 30, 1997. When the new subcontractor is identified and aboard, the test plan for Phase 2 will be prepared. It will include the detailed plan for the field work and related laboratory activities.

The two graduate students assigned to this project will continue their scholarly work during this quarter. 


\section{INTRODUCTION}

This eighth quarterly report describes work done during the eighth three-month period of the University of Pittsburgh's project on the "Treatment of Metal-Laden Hazardous Wastes with Advanced Clean Coal Technology By-Products."

This report describes the activities of the project team during the reporting period. The principal work has focussed upon new laboratory evaluation of sandblast residue treated with two by-products, seeking a subcontractor to replace Mill Service, Inc. (MSI) for the field work of Phase 2, preparing and giving presentations, and making and responding to a number of outside contacts. 


\section{LABORATORY AND FIELD WORK}

\section{Laboratory Analyses}

Phase 1 laboratory work at the University of Pittsburgh was continued through the quarter. The work consisted of further testing of the solidification of the seventh hazardous waste - the sandblast residue from paint removal in a building - and examining the microstructure of the products of solidification. It also included the evaluation of the stabilization of successful treatment products after one year had passed. This work essentially comprised the scholarly activities of the graduate students.

\section{Solidification Testing of Treated Sandblast Residue}

During the quarter, solidification tests were conducted for successful treatments of the sandblast residue. There were two treated waste mixtures which demonstrated immediate stabilization, the sandblast residue $\mathrm{w} / 30 \%$ spray drier residue (CONSOL) and the sandblast residue $w / 50 \%$ PFBC residue (Tidd). For these two mixtures, a water-containing blend having a 1-2" slump was prepared out at the Yukon plant of MSI. Each of these mixtures was prepared by placing a measured weight of by-product into a 32 " $\times 21$ " $\times 9$ " plastic mortar box. A measured weight of sandblast residue was then added to the mortar box and the mixture blended with a cement hoe until well mixed. A measured volume of water was then added to the mixture and blended until thoroughly mixed. The slump of the mixture was tested as per the requirements of ASTM C 143-90a - "Test Method for Slump of Hydraulic Cement Concrete." Once the desired slump was obtained, the mixture was compacted into $3^{\text {" }} \times 6^{\text {" cardboard }}$ cylinders as per ASTM C 192-90a - "Standard Practice for Making and Curing Concrete Test Specimens in the Laboratory." The cylinders were then covered with plastic in order to prevent moisture loss and allowed to set up for 24 hours. Following the setup period, the samples were transported back the university campus, the molds were stripped off, and the specimens placed in an environmentally controlled room with a relative humidity of $100 \%$. A summary of the treatments prepared for solidification testing during the quarter using this methodology is given in Table 1.

TABLE 1: Treatment of the Sandblast Residue for Solidification Testing

\begin{tabular}{|c|c|c|c|c|}
\hline $\begin{array}{c}\text { Sample } \\
\text { Identification }\end{array}$ & $\begin{array}{c}\text { Weight of By- } \\
\text { Product (lbs) }\end{array}$ & $\begin{array}{c}\text { Weight of } \\
\text { Waste (lbs) }\end{array}$ & $\begin{array}{c}\text { Volume of } \\
\text { Water (L) }\end{array}$ & $\begin{array}{c}\text { Slump } \\
\text { (inches) }\end{array}$ \\
\hline $\begin{array}{c}\text { Sandblast Waste } \\
\text { w/30\% CONSOL }\end{array}$ & 20 & 60 & 8.5 & 1.75 \\
\hline $\begin{array}{c}\text { Sandblast Waste } \\
\text { w/50\% Tidd }\end{array}$ & 22 & 44 & 5.0 & 1.5 \\
\hline
\end{tabular}


Following specified curing times of $3,7,14$, and 28 days, the compressive strength of the treated sandblast residue mixtures was evaluated according to ASTM C 39-86 - "Test Method for Compressive Strength of Cylindrical Concrete Specimens." The sandblast residue $w / 30 \%$ CONSOL did not undergo solidification sufficient enough to conduct compressive strength tests. A summary of the solidification tests performed on the treated sandblast residue $w / 50 \%$ Tidd is given in Table 2 .

TABLE 2: Compressive Strength of the Sandblast Residue Treated with $50 \%$ Tidd

\begin{tabular}{|c|c|}
\hline Curing Time (days) & Compressive Strength (psi) \\
\hline 3 & Not Solidified \\
\hline 7 & 13 \\
\hline 14 & 18 \\
\hline 28 & 20 \\
\hline
\end{tabular}

\section{Metals Analysis of Treated Sandblast Residue}

During the quarter, immediate ASTM extraction for heavy metals leachability were performed on the two treated sandblast residue samples according to ASTM D 3987-85 - "Test Method for Shake Extraction of Solid Waste with Water." The results of the ASTM analyses of all 15 metals are presented in an internal white paper entitled "Treatment of Sandblast Waste With By-Products From Clean Coal Technologies." A copy of this paper can be found in Appendix A.

In addition to the immediate ASTM metals analyses, TCLP lead analyses were performed on the two treated sandblast residue mixtures after curing for a period of 28 days each. Table 3 gives the resulting TCLP lead concentrations of these two treatments in milligrams of contaminant per liter of leachant.

TABLE 3: TCLP Lead Concentrations of Treated Sandblast Residue

\begin{tabular}{|c|c|c|}
\hline Sample Identification & $\begin{array}{c}\text { Curing Time } \\
\text { (days) }\end{array}$ & $\begin{array}{c}\text { TCLP Pb Concentration } \\
\text { (mg/L) }\end{array}$ \\
\hline $\begin{array}{c}\text { Sandblast Residue } \\
\text { w/30\% CONSOL }\end{array}$ & 28 & 0.24 \\
\hline $\begin{array}{c}\text { Sandblast Residue } \\
\text { w/50\% Tidd }\end{array}$ & 28 & 67.80 \\
\hline
\end{tabular}


Table 3 shows that the long term stabilization of the sandblast residue treated with $30 \%$ CONSOL was successful in decreasing the leachable lead concentration to well below the current BDAT standard of $5 \mathrm{mg} / \mathrm{L}$. The long term stabilization of the sandblast residue treated with $50 \%$ Tidd, however, was not successful as the leachable lead concentration after 28 days was well above the current BDAT standard.

\section{Fourth By-Product}

No further discussions were held with JTM's Northeastern Regional Office.

Deborah Hassett of the University of North Dakota's Energy and Environment Research Center suggested contacts at two midwestern universities that operate coal-fired fluid bed combustors - lowa State University and Purdue University.

\section{Scholarly Activity}

The two graduate students continued work towards their respective Master's theses during the quarter.

Ms. Clifford performed the TCLP lead analyses on the two treated sandblast residue mixtures after curing times of $1,3,7,14$, and 28 days each. She also performed microscopic evaluations of the treated sandblast waste mixtures after these same curing times, in addition to the raw materials used, by both $x$-ray diffraction and scanning electron microscopy. The results of these continuing analyses will be reported in the next quarterly report.

Mr. Pritts performed long term solidification tests and TCLP lead analyses on ten different treated waste mixtures during the quarter. A summary of the results of these long term evaluations is given in Table 4.

A comparison of the one-year TCLP with the immediate and 90-day TCLPs is shown in Table 5. It can be seen that in general the stability of the residues treated with CONSOL and Tidd by-products degrades from 90 days to one year, while those treated with Ebensburg byproduct are more stable at one year than at 90 days. It should be recalled that the immediate TCLP was determined for small samples treated at Mill Service, Inc., while the 90-day and oneyear TCLPs were performed on fragments of cylinders produced for solidification tests. Thus, it may not be completely valid to compare the immediate TCLP with the other two.

Two undergraduates and a research associate in the Department of Chemical and Petroleum Engineering have made interesting contributions to the project during this quarter:

- Sarah Spencer, a participant in the Research Experience for Undergraduates (REU) Program of the department, sponsored by the National Science Foundation;

- Jana Agostini, a senior in the department who has enrolled this fall in the Environmental Engineering Program of the Department of Civil and Environmental Engineering; 
TABLE 4: Long Term Evaluations of Solidified Wastes

\begin{tabular}{|c|c|c|c|}
\hline $\begin{array}{c}\text { Sample } \\
\text { Identification }\end{array}$ & $\begin{array}{l}\text { Curing Time } \\
\text { (days) }\end{array}$ & $\begin{array}{l}\text { Compressive } \\
\text { Strength } \\
\text { (psi) }\end{array}$ & $\begin{array}{c}\text { TCLP Lead } \\
\text { Concentration } \\
\text { (mg/L) }\end{array}$ \\
\hline $\begin{array}{c}\text { CONSOL/Battery } \\
\text { Manufacturing Sludge }\end{array}$ & 419 & 40 & 3.56 \\
\hline $\begin{array}{c}\text { Ebensburg/Munitions } \\
\text { Depot Soil }\end{array}$ & 419 & 165 & 0.49 \\
\hline Tidd/Industrial Soil & 405 & 312 & 20.48 \\
\hline $\begin{array}{c}\text { CONSOL/Munitions } \\
\text { Depot Soil }\end{array}$ & 399 & 27 & 1.07 \\
\hline $\begin{array}{c}\text { Tidd/Battery } \\
\text { Manufacturing Sludge }\end{array}$ & 399 & 190 & 4.16 \\
\hline $\begin{array}{c}\text { Tidd/Munitions Depot } \\
\text { Soil }\end{array}$ & 370 & 133 & 1.74 \\
\hline Tidd/WWTP Soil & 335 & 472 & 1.12 \\
\hline Ebensburg/WWTP Soil & 335 & 120 & 0.65 \\
\hline $\begin{array}{c}\text { Tidd/Munitions Depot } \\
\text { Soil Proctor }\end{array}$ & 348 & 186 & 3.64 \\
\hline $\begin{array}{c}\text { Ebensburg/WWTP Soil } \\
\text { Proctor }\end{array}$ & 327 & 39 & 0.53 \\
\hline
\end{tabular}

- Guansheng Yin, a research associate on leave for the summer from the Xian Highway University, Peoples Republic of China.

Ms. Spencer assisted Ms. Clifford in the TCLP evaluation of the sandblast residue and the ASTM leachate evaluation of that residue treated with the CONSOL and Tidd by-products. As mentioned earlier, her report on the ASTM work is given in Appendix A.

Ms. Agostini investigated the possibility of permeability studies of the solidification samples. Her report is given in Appendix B. No follow-up is anticipated in the near future on her recommendations.

Mr. Yin evaluated the stabilization recipes of the project, based upon his experience in by-product utilization in China. His report is given in Appendix C. 
TABLE 5: TCLP History of Solidified Wastes (concentrations in $\mathrm{mg} / \mathrm{L}$ )

\begin{tabular}{|c|c|c|c|}
\hline $\begin{array}{c}\text { Sample } \\
\text { Identification }\end{array}$ & $\begin{array}{c}\text { TCLP Lead } \\
\text { Immediate }\end{array}$ & $\begin{array}{c}\text { TCLP Lead } \\
\text { 90-Day }\end{array}$ & $\begin{array}{c}\text { TCLP Lead } \\
\text { One-Year }\end{array}$ \\
\hline $\begin{array}{c}\text { CONSOL/Battery } \\
\text { Manufacturing Sludge }\end{array}$ & 0.2 & $<0.5$ & 3.6 \\
\hline $\begin{array}{c}\text { Ebensburg/Munitions } \\
\text { Depot Soil }\end{array}$ & 5.0 & 9.0 & 0.5 \\
\hline Tidd/Industrial Soil & 1.7 & 14.0 & 20.5 \\
\hline $\begin{array}{c}\text { CONSOL/Munitions } \\
\text { Depot Soil }\end{array}$ & 0.3 & 0.9 & 1.1 \\
\hline $\begin{array}{c}\text { Tidd/Battery } \\
\text { Manufacturing Sludge }\end{array}$ & 4.6 & 0.7 & 4.2 \\
\hline $\begin{array}{c}\text { Tidd/Munitions Depot } \\
\text { Soil }\end{array}$ & 0.8 & 1.2 & 1.8 \\
\hline Tidd/WWTP Soil & 2.2 & 0.6 & 1.1 \\
\hline Ebensburg/WWTP Soil & 0.2 & 6.0 & 0.7 \\
\hline
\end{tabular}

\section{Preparation for Field Work}

The NEPA Checklist was sent to Envirite Corporation on July 1, 1996, along with an invitation to join the project team. On July 10,1996 Envirite formally declined to participate. The exchange of correspondence is given in Appendix $D$. In a telephone conversation it was noted that the reasons for rejection were:

- incomplete cycle of approval of Part B permit;

- lack of operational, economic or business advantage;

- concern for federal involvement.

On July 25, 1996 a letter similar to the one to Envirite was sent to EO Company in Ypsilanti, Michigan, and on September 10, 1996 another was sent to Heritage Environmental Services, Inc., in Indianapolis, Indiana. Responses from both companies are being awaited. 


\section{REPORTS AND PRESENTATIONS}

On August 2, 1996 the project's co-principal investigator, Professor Ronald D. Neufeld, was informed that the paper submitted in April 1996 for publication in Water Science and Iechnology on "Hazardous Waste Stabilization with Clean-Coal Technology Ash Residuals" has been accepted for publication.

Sarah Spencer, the REU summer student introduced in the preceding section, gave a fifteen-minute presentation in the REU symposium at the university on August 7, 1996. The symposium's program is given in Appendix E. 


\section{OUTSIDE CONTACTS}

\section{American Society for Testing and Materials}

On July 19, 1996 the Principal Investigator, Prof. J. T. Cobb, attended the meeting in Annapolis, Maryland, of the E50.03 subcommittee of the American Society for Testing and Materials (ASTM). The subcommittee discussed five future standards on which much development work is required:

- Standard Guide for Use of Coal Combustion By-Products in Structural Fills

- Standard for Chemical Stabilization (Fixation) of Selenium and Arsenic

- Standard Guide to Coal Combustion By-Product Applications in Soil Amendment and Mine Backfill

- Standard Guide for Coal Combustion By-Product Specification for Industrial Mineral Uses

- Standard Guide for the Use of Coal Ash to Solidify and Stabilize Wastes

The PI informed the committee of the current project and of the basic interest of the project team in applying its experience in this project to the last standard guide on the list. As results of the field test become available for direction, the project team plans to begin working with the E50.03 subcommittee.

\section{Dravo Lime Company}

Prof. Cobb and Mr. Yin, the research associate from China, introduced in a preceding section, met twice with staff members of Dravo Lime Company (DLC). Both meetings were attended by Shiaw Tseng, the first one by Joel Beegly and the second one by Robert Roden.

In the first meeting it was agreed that the U.S. and China both have comparable technology for ash-lime-soil road base. DLC recommended that China could use more coal combustion by-products in grout (flowable fill). China should also begin to work with clean coal technology by-products.

The focus of the second meeting was placed upon wet flue gas desulfurization processes using lime or mag-lime sorbents. There was considerable discussion of lime sources in China and the role that DLC could play in advising on this topic in general, as well as the possibility of marketing its technology in that country.

DLC followed up on this discussion by participating in the second meeting of the Pennsylvania Energy Consortium on September 6, 1996 in Pittsburgh. The consortium is being designed as a bidding consortium to target projects in China that include coal mine develop- 
ment, mine fire extinguishment, power plant construction, transmission line construction, ash handling and disposal, and related infrastructure work.

\section{Miscellaneous Tooics in Coal Combustion By-Product Utilization}

Prof. Neufeld has engaged in a series of conversations with the Center for Economic Operations of Indiana, Pennsylvania, and Basic Industry Technology, Inc., of Chula Vista, California, regarding a technology producing a ceramic-like structure at ambient temperature, using coal combustion by-products (CCBs) and agricultural waste products. The process has been developed by Arcilla Research of the Netherlands, and confirmed by Delft University of Technology.

Prof. Neufeld received a brief description of proposed regulations by the Pennsylvania Department of Environmental Protection (DEP), related to this project:

"DRAFT TITLE: Certification Guidelines for the Beneficial Uses of Coal Ash. BACKGROUND: These guidelines are necessary for the review of the use of coal ash for beneficial purposes under the residual waste management regulations in Chapter 287. DEP is drafting these guidelines because of changes to these regulations that are to be submitted as proposed final regulations before the Environmental Quality Board meeting in September 1996. ANTICIPATED EFFECTIVE DATE: December 1996. ANTICIPATED DRAFT DEVELOPMENT DATE: September 1996 (Department draft). PROPOSED DEVELOPMENT AND REVIEW PROCESS: The Bureau of Mining and Reclamation, District Mining Operations, Bureau of Land Recycling and Waste Management and Bureau of Abandoned Mine Reclamation are to be involved in the initial development. This draft will be presented to the Mining and Reclamation Advisory Board, the Pennsylvania Coal Association and the Pennsylvania Mining Professionals for review and comments. CONTACT: Alfred Dalberto at (717)783-8845."

Profs. Cobb and Neufeld visited with staff members of West Virginia University on September 27, 1996 to discuss mutual interests in the production of autoclaved cellular concrete using CCBs. 


\section{ADMINISTRATIVE ASPECTS}

This section reports on two special administrative actions, provides the monthly highlights, and closes by comparing progress with the milestone chart.

\section{Special Actions}

Because the project has not been brought to a conclusion during the two years originally allocated to it, a no-cost contract extension was requested on August 20, 1996, by letter from the Principal Investigator and the Director of the Office of Research of the university. The Contracting Officer's Representative for the project informed the project team by telephone on September 18, 1996 that, as a result of a recent change in regulations, the no-cost contract extension is automatic upon the request of the prime contractor. Thus, the project will continue through September 30, 1997.

On September 27, 1996, immediately following their visit to West Virginia University, the Principal and Co-Principal Investigators met with the Contracting Officer's Representative to brief him on the current status of the project.

\section{Monthly Highlights}

Here are the highlights of the third three months of the second phase of the project.

June 30 - July 30.1996

- Solidification tests of the sandblast residue with $30 \%$ spray drier residue and with $50 \%$ PFBC residue are initiated.

- Envirite Corporation declines to participate in Phase 2.

- EO Company is invited to participate in Phase 2.

- Principal investigator and research associate hold discussions on by-product utilization in China with Dravo Lime Company.

- Principal investigator attends the ASTM E50.03 subcommittee meeting in Annapolis, Maryland.

July 30 - August 30,1996

- TCLP and ASTM extractions for heavy metals leachability are performed for the two sandblast residue solidification products, showing reduced effectiveness of the PFBC residue over time. 
- Paper in Water Science and Technology is accepted.

- REU summer student presents results of her project at the REU symposium at the University of Pittsburgh.

- No-cost extension of the contract is invoked by the university.

\section{August 30 - September 30.1996}

- One-year solidification samples are extracted by TCLP for heavy metals leachability, showing generally a long-term reduction in stabilization.

- Heritage Environmental Services, Inc., is invited to participate in Phase 2.

- Principal and co-principal investigators visit West Virginia University to discuss autoclaved cellular concrete using coal combustion by-products.

\section{Comparison of Progress with Milestone Chart}

The following task for Phase 2 had been scheduled for completion during the first quarter of Phase 2:

- Task 1 - Test Plan for Phase 2

Task 1 still was not completed during the fourth period of this phase. The decision in early April 1996 by METC that an environmental assessment of the Phase 2 project at the Yukon plant of Mill Service, Inc., would have to be conducted and the subsequent withdrawal in late April 1996 by MSI from Phase 2 has necessitated a search for a new subcontractor to host and participate in the commercial test of Phase 2. The test plan for Phase 2 cannot be specified in sufficient detail for presentation until the new subcontractor is identified and can participate in its preparation.

The sixth and seventh quarterly technical report were submitted during the eighth quarter.

Work was completed on one task from Phase 1:

- Task 3 - Sample Collection and Characterization

Work continued on two tasks from Phase 1:

- Task 4 - Treatment of Metal-Laden Waste with CCT Solid By-Product

- Task 5 - Data Analysis 
Work on Tasks 4 and 5 of Phase 1 will continue into the fifth quarter of Phase 2. The fourth by-product and the final three residues are no longer being actively sought. When the Phase 2 testing program is initiated, consideration will be given to reestablishing this activity. 


\section{PLAN FOR THE NEXT QUARTER}

During the quarter from September 30 through December 30,1996 , work will continue on Tasks 4 and 5 of Phase 1.

Work on Task 1 of Phase 2 will continue. Because of the delay in initiating the commercial tests of Phase 2, caused by the withdrawal of MSI from Phase 2 and the extended search for a new subcontractor, the project team has invoked a one-year no-cost extension to the contract to September 30, 1997. When the new subcontractor is identified and aboard, the test plan for Phase 2 will be prepared. It will include the detailed plan for the field work and related laboratory activities.

The two graduate students assigned to this project will continue their scholarly work during this quarter. 
APPENDIX A

TREATMENT OF SANDBLAST WASTE WITH BY-PRODUCTS FROM CLEAN COAL TECHNOLOGIES 


\title{
Treatment Of Sandblast Waste With By-Products From Clean Coal Technologies
}

\author{
Sarah V. Spencer \\ Advisor: James T. Cobb \\ Graduate Students: Vourneen Clifford and Jesse Pritts \\ REU Program, Chemical Engineering Department \\ University of Pittsburgh
}




\section{ABSTRACT:}

The purpose of this work is to treat hazardous waste with clean coal technology by-products in order to stabilize and decrease risks from exposure to this hazardous waste. The clean coal technologies were developed to reduce the atmospheric emission of $\mathrm{SO}_{2}$. In the process by-products are generated which contain lime. Due to their lime content, these by-products have relatively high $\mathrm{pH}$ values. These high $\mathrm{pH}$ values may help limit the solubility of many of the metals. If successful, the heavy metals can then be stabilized and these by-products can be used as commerical treatment products, instead of being solid wastes which must be placed in a landfill. 
TITLE:

OBJECTIVE:

BACKGROUND:
Treatment Of Sandblast Waste With By-Products From Clean Coal Technologies.

To treat hazardous waste with clean coal technology byproducts in order to stabilize and decrease risks from exposure to this hazardous waste.

The by-products that were used to treat the Sandblast Waste have been collected from a spray dry scrubber and fluid bed combuster. "A fluidized bed combustion (FBC) is a process of burning crushed coal in a bed of limestone particles held in suspension by the upward flow of combustion air entering a chamber through a perforated air distribution grid below the fluidized bed."1 However, "... the dry scrubber residue is collected from a process, where ash laden flue gas enters the bottom of the spray drier and all of the sulfur-capture residue rises through the upper port with fly ash."1

These clean coal technology by-products are different from regular coal fly ash in that they contain lime. The use of lime limits the $\mathrm{SO}_{2}$ in the stack gas leaving the power plants and thus reduces acid rain. Due to their lime content the $\mathrm{pH}$ values of these by-products are high. This results in a favorable characteristic for treating metal-laden hazardous wastes, as many metals are less soluble at high $\mathrm{pH}$ values.

Sandblast Waste is the residue from sandblasted lead paint. The sandblasting procedure consists of mixing sand and water, then the mixture is blasted on the painted area at a high pressure. Thus causing the paint to chip and fall off. The awareness of lead hazards has increased due to the publicity of lead poisoning and the creation of the Occupational Safety and Health Administration's (OSHA) Lead Standard Act, 29 CFR1926.62. ${ }^{2}$

Lead paint is so harmful as a result of its adverse affects on small children. Lead poisoning in small children causes unnecessary and unfavorable elevated blood lead levels among children, thus causing numerous ailments and disabilities. Accordingly in 1971 Congress passed "The Lead Bases Paint Poisoning Prevention Act" whose purpose was to remove lead paint from houses and prohibit the use of lead-based paint. 
Likewise the Consumer Product Safety Commission (CPSC) determined that the new paint can contain only $0.06 \%$ lead by weight. Accordingly paint and similar coatings with a lead content in excess of $0.06 \%$ lead by weight are considered "lead-based paints" which are hazardous materials. Also the permissible exposure limit (PEL) for lead in the air in the construction industry is 50 $\mathrm{ug} / \mathrm{m}^{3}$ averaged over an 8-hour period. "In conjunction OSHA set the lead action level at $30 \mathrm{ug} / \mathrm{m}^{3}$, which is in line with the General Industry Standard."2 For further reference the lead standards for drinking water is $5 \mathrm{mg} / \mathrm{L}$.

Nonetheless a total of 15 metals were analyzed to see if any hazardous metal levels exist. Therefore, refer to the table titled Metal Analysis Of Wastes to see introductory metal levels.

MATERIALS \& METHODS:

RESULTS:
The Sandblast Waste was collected from Mill Service, a hazardous waste treatment facility. The Sandblast Waste was then mixed with $50 \%$ of the fluid bed combuster byproduct and another batch of the waste was mixed with $30 \%$ of the spray dry scrubber by-product. The treated waste was then brought back to the University of Pittsburgh to be analyzed. The solid wastes were extracted with water, then the extracted wastes were filtered. These procedures were followed by acid digestions. After the digestion, the wastes were analyzed on the Atomic Absorption Spectrophotometer (AA).

The metals were analyzed on the AA using three different methods. The first method, graphite furnace atomic absorption was used to examine the following metals: antimony, arsenic, barium, beryllium, selenium, thallium, and vanadium. The second method used, flame atomic absorption successfully analyzed these metals: cadmium, chromium, copper, lead, nickel, silver, and zinc. While the cold vapor atomic absorption technique only examined mercury. In total 15 metals were analyzed.

A quality control plan was used to verify the results. This plan consisted of spiked blanks, DI water blanks, and duplicate samples.

Refer to the table Metal Analysis Of The By-Product/ Waste Mixtures for results. As expected lead was the only 
metal of concern.

There are no standards to compare the American Society for Testing Materials (ASTM) results, however to get a relative idea of what these numbers mean one should compare the results to the drinking water and the Best Demonstrated Available Technology (BDAT) standards. BDAT standards are used to compare the treated waste results prior to disposal of the wastes in a landfill. The BDAT standards apply to an acid leachate, known as Toxicity Characteristic Leaching Procedure (TCLP). While the ASTM samples are water leachate. These two standards are simply presented to only give some comparison to the ASTM values obtained.

DISCUSSION:

\section{REFERENCES:}

Cobb, James T., et al (February 1995). "Treatment Of Metal-Laden Hazardous Wastes With Advanced Clean Coal Technology By-Products." U. S. Department of Energy DE-FC2194MC31175, Quarterly Report.

Coluccio, Vincent M. Lead-Based Paint Hazards. Van Nostrand Reinhold: New York, New York. 1994. 
TABLE 1: METALS ANAYLYSIS OF THE WASTE

\begin{tabular}{|c|c|c|c|c|c|}
\hline & & & $\overline{\text { BDATS }}$ & tandard & \\
\hline & Property & Units & Current & Future & Sandblast Waste \\
\hline Total Metals & Antimony (Sb) & $\mathrm{mg} / \mathrm{kg}$ & 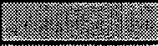 & - & 5.1 \\
\hline & Arsenic (As) & $\mathrm{mg} / \mathrm{kg}$ & 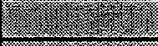 & - - & $<20$ \\
\hline & Barium (Ba) & $\mathrm{mg} / \mathrm{kg}$ & 12 & =- & 60 \\
\hline & Beryllium (Be) & $\mathrm{mg} / \mathrm{kg}$ & $\sqrt{17030}$ & 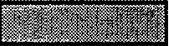 & $<0.089$ \\
\hline & Cadmium (Cd) & $\mathrm{mg} / \mathrm{kg}$ & 10.707 .07 & $1.2-2.7 \%$ & 2 \\
\hline & Chromium (Cr) & $\mathrm{mg} / \mathrm{kg}$ & 20 & - & 9.2 \\
\hline & Copper (Cu) & $\mathrm{mg} / \mathrm{kg}$ & 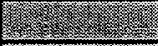 & I & 29 \\
\hline & Lead $(\mathrm{Pb})$ & $\mathrm{mg} / \mathrm{kg}$ & 1.7. & 1.7. & 43000 \\
\hline & Mercury $(\mathrm{Hg})$ & $\mathrm{mg} / \mathrm{kg}$ & - & 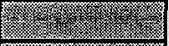 & 0.19 \\
\hline & Nickel (Ni) & $\mathrm{mg} / \mathrm{kg}$ & 2 & 20.73 & $<10$ \\
\hline & Selenium (Se) & $\mathrm{mg} / \mathrm{kg}$ & 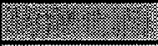 & I & 0.26 \\
\hline & Silver $(\mathrm{Ag})$ & $\mathrm{mg} / \mathrm{kg}$ & 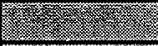 & 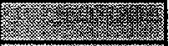 & $<2.0$ \\
\hline & Thallium (TI) & $\mathrm{mg} / \mathrm{kg}$ & 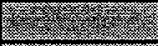 & 28 & $<0.45$ \\
\hline & Vanadium ( $\mathrm{V}$ ) & $\mathrm{mg} / \mathrm{kg}$ & 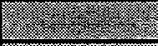 & Jer & 1.29 \\
\hline & Zinc $(\mathrm{Zn})$ & $\mathrm{mg} / \mathrm{kg}$ & 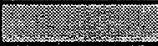 & 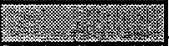 & 59 \\
\hline TCLP Metal & Antimony (Sb) & $\mathrm{mg} / \mathrm{L}$ & - & 2.1 & 0.051 \\
\hline & Arsenic (As) & $\mathrm{mg} / \mathrm{L}$ & 5.0 & 5.0 & $<.10$ \\
\hline & Barium (Ba) & $\mathrm{mg} / \mathrm{L}$ & 100.0 & 7.6 & $<5.0$ \\
\hline & Beryllium (Be) & $\mathrm{mg} / \mathrm{L}$ & - & 0.014 & $<0.001$ \\
\hline & Cadmium (Cd) & $\mathrm{mg} / \mathrm{L}$ & 1.0 & 0.19 & $<.10$ \\
\hline & Chromium (Cr) & $\mathrm{mg} / \mathrm{L}$ & 5.0 & 0.86 & $<.10$ \\
\hline & Copper $(\mathrm{Cu})$ & $\mathrm{mg} / \mathrm{L}$ & - & - & 0.28 \\
\hline & Lead $(\mathrm{Pb})$ & $\mathrm{mg} / \mathrm{L}$ & 5.0 & 0.37 & 350 \\
\hline & Mercury $(\mathrm{Hg})$ & $\mathrm{mg} / \mathrm{L}$ & 0.2 & $0.20 / 0.025$ & $<.010$ \\
\hline & Nickel (Ni) & $\mathrm{mg} / \mathrm{L}$ & - & 5.1 & $<.10$ \\
\hline & Selenium (Se) & $\mathrm{mg} / \mathrm{L}$ & 1.0 & 0.16 & $<.10$ \\
\hline & Silver $(\mathrm{Ag})$ & $\mathrm{mg} / \mathrm{L}$ & 5.0 & 0.3 & $<.10$ \\
\hline & Thallium (TI) & $\mathrm{mg} / \mathrm{L}$ & - & 0.078 & $<0.005$ \\
\hline & Vanadium $(\mathrm{V})$ & $\mathrm{mg} / \mathrm{L}$ & - & 0.23 & $<0.01$ \\
\hline & Zinc (Zn) & $\mathrm{mg} / \mathrm{L}$ & - & 5.3 & 1.7 \\
\hline
\end{tabular}

* BDAT standards do not apply to shaded areas. 
TABLE 2: Metal Analysis Of The By-Product/ Waste Mixtures

\begin{tabular}{|c|c|c|c|c|}
\hline & & & Sandblast Waste & Sandblast Waste \\
\hline & Property & Units & w/ $30 \%$ Consol & $w / 50 \%$ Tidd \\
\hline ASTM Metals & Antimony (Sb) & $\mathrm{mg} / \mathrm{L}$ & $<0.02$ & $<0.02$ \\
\hline 24 hours & Arsenic (As) & $\mathrm{mg} / \mathrm{L}$ & $<0.01$ & $<0.01$ \\
\hline & Barium (Ba) & $\mathrm{mg} / \mathrm{L}$ & 0.15 & 0.46 \\
\hline & Beryllium (Be) & $\mathrm{mg} / \mathrm{L}$ & $<0.001$ & $<0.001$ \\
\hline & Cadmium (Cd) & $\mathrm{mg} / \mathrm{L}$ & $<0.05$ & $<0.05$ \\
\hline & Chromium (Cr) & $\mathrm{mg} / \mathrm{L}$ & $<0.5$ & $<0.5$ \\
\hline & Copper (Cu) & $\mathrm{mg} / \mathrm{L}$ & $<0.05$ & $<0.05$ \\
\hline & Lead (Pb) & $\mathrm{mg} / \mathrm{L}$ & 75.3 & 4.8 \\
\hline & Mercury $(\mathrm{Hg})$ & $\mathrm{mg} / \mathrm{h}$ & $<0.0025$ & $<0.0025$ \\
\hline & Nickel (Ni) & $\mathrm{mg} / \mathrm{L}$ & $<0.3$ & $<0.3$ \\
\hline & Selenium (Se) & $\mathrm{mg} / \mathrm{L}$ & $<0.01$ & 0.013 \\
\hline & Silver $(\mathrm{Ag})$ & $\mathrm{mg} / \mathrm{L}$ & $<0.05$ & $<0.05$ \\
\hline & Thallium (TI) & $\mathrm{mg} / \mathrm{L}$ & $<0.005$ & $<0.005$ \\
\hline & Vanadium (V) & $\mathrm{mg} / \mathrm{L}$ & $<0.01$ & $<0.01$ \\
\hline & Zinc $(Z n)$ & $\mathrm{mg} / \mathrm{L}$ & 0.05 & $<0.05$ \\
\hline
\end{tabular}




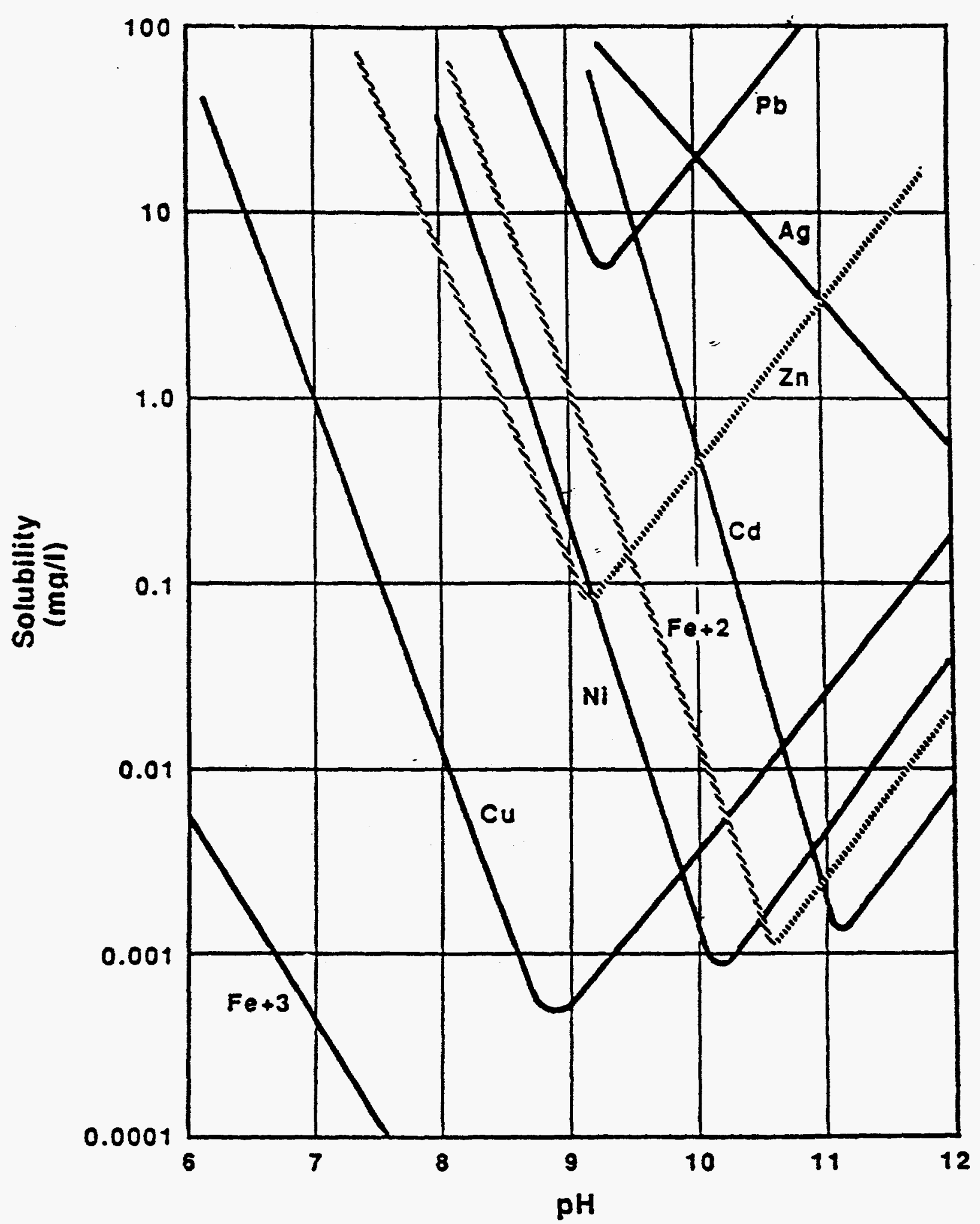

Figure 3-2 Solubilities of metal hydroxides as a function of pH. (From EPA [17].) 


\section{APPENDIX B}

OVERVIEW OF PERMEABILITY STUDIES ON CONCRETE CYLINDERS 


\title{
Overview of
}

\section{Permeability Studies}

\section{on Concrete Cylinders}

"Treatment of Metal-Laden Hazardous Wastes with Advanced Clean Coal Technology By-Products"

\author{
Prepared by: \\ Jana Agostini \\ Chemical and Petroleum Engineering Department \\ University of Pittsburgh \\ 28 June 1996
}




\section{INTRODUCTION}

This perspectus examines the use of permeability studies in broadening the scope of the project titled "Treatment of Metal Laden Hazardous Wastes with Advanced Clean Coal Technology By-Products." Determining the permeabilities of water through the concrete cylinders prepared during the solidification testing portion of the project will provide further insight into the use of the treated wastes in applications such as for structural fills or as landfill caps.

\section{EQUIPMENT DESCRIPTION}

A permeameter measures the permeability of a soil, rock, clay, or other porous material with the permeant (in our case, water). Permeability is the ease with which water can move through the sample. Since fluid flow takes place in the pore system, the structure of the pore system and the porosity of the material are significant. The permeability of a sample is measured by the hydraulic conductivity or the coefficient of permeability, K. K can be determined from Darcy's Law for flow through a porous media, such that $K=Q U A H$. In the laboratory determination of $K$, using a permeameter, water is allowed to flow through a sample of cross sectional area, $A$, and length, $L$, with a hydraulic head, $H$. The flow rate, $Q$, is measured by collecting the accumulated discharge over a given time interval.

Table 1, taken from Hydrology and Hydraulics by Rafael Quimpo, provides some physical characteristics of selected samples. 


\begin{tabular}{|l|c|c|c|}
\hline \multicolumn{1}{|c|}{ Type of Sample } & $\begin{array}{c}\text { Porosity, } \mathbf{p} \\
\text { (percent) }\end{array}$ & $\begin{array}{c}\mathbf{K} \\
\text { (gpd/ft } \mathbf{t}^{2}\end{array}$ & $\begin{array}{c}\mathbf{K} \\
\text { (cm/sec) }\end{array}$ \\
\hline Clay & $45-55$ & $0.001-2$ & $4.7 \mathrm{e}^{-8}-9.4 \mathrm{e}^{-5}$ \\
\hline Sand & $35-40$ & $100-3,000$ & $0.0047-0.14$ \\
\hline Gravel & $30-40$ & $1,000-15,000$ & $0.047-0.71$ \\
\hline Sand and Gravel & $20-35$ & $200-5,000$ & $0.0094-0.236$ \\
\hline Sandstone & $10-20$ & $0.1-50$ & $4.7 \mathrm{e}^{-6}-0.0024$ \\
\hline Shale & $1-10$ & $0.0001-1$ & $4.7 \mathrm{e}^{-9}-4.7 \mathrm{e}^{-5}$ \\
\hline Limestone & $1-10$ & $0.0001-1$ & $4.7 \mathrm{e}^{-9}-4.7 \mathrm{e}^{-5}$ \\
\hline
\end{tabular}

Table 1: Physical Characteristics of Selected Samples

As a first guess, the expected permeabilities of the concrete cylinders will range from $10^{-6}$ to $10^{-7} \mathrm{~cm} / \mathrm{s}$.

Figure 1 shows a basic diagram of a permeability cell, similar to the one we will use. The sample in encased in a latex sheath and is surrounded and pressurized by water. The clay plate is shown at the bottom of the sample. The discharged water is collected in a graduated tube.

Figure 1: Cross-sectional View of a Basic Permeability Cell

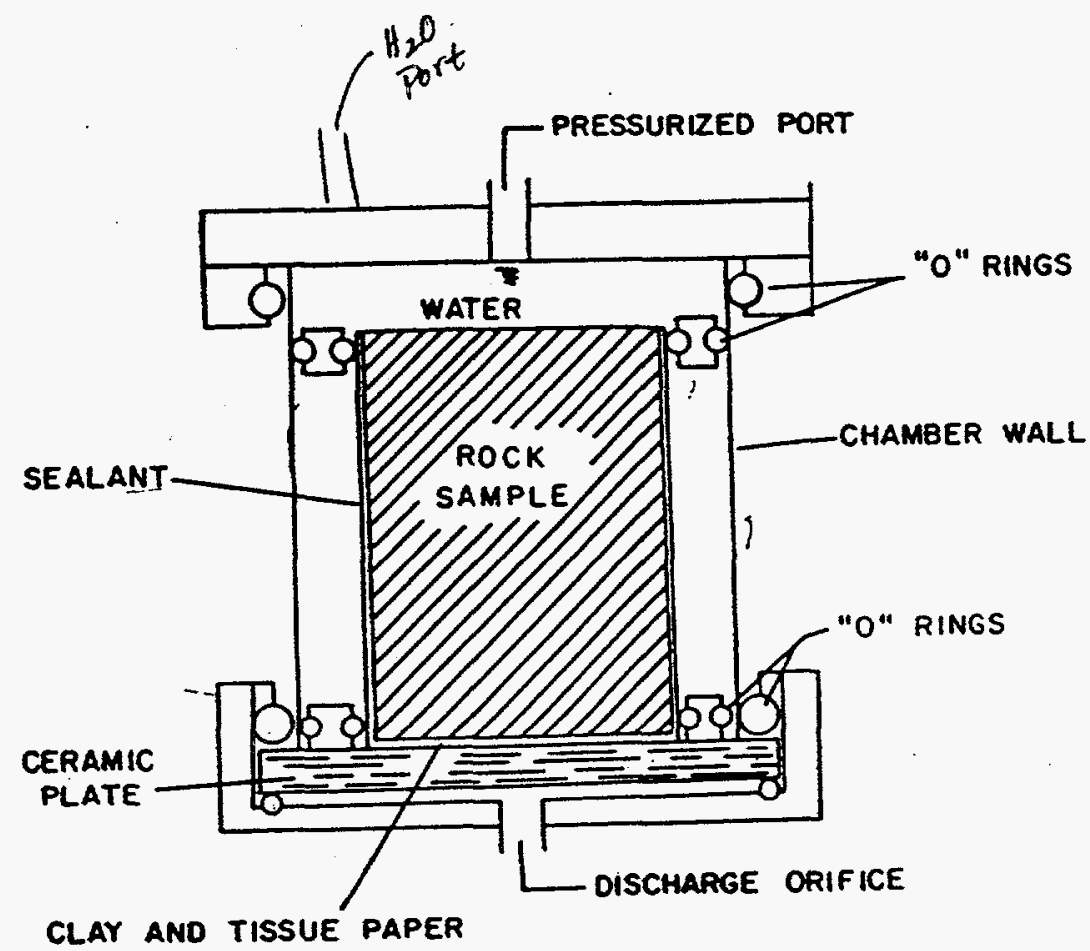




\section{BACKGROUND}

The initial plan was to design and build a high pressure permeameter cell capable of withstanding pressures of several hundred psi necessary to determine the permeability of a hardened sample in a reasonable amount of time. In developing a preliminary design for the permeability cell, I spoke with two faculty, one graduate student, and one technician. A basic design of a permeability cell was completed, including the dimensions of the unit. However, specifications on the placement of the water and pressurization ports on the aluminum head assembly and base, as well as the design of a distribution plate within the cell to distribute the water equally over the surface of the cylinder, inhibited the construction of the permeability cell.

In an effort to gain more insight in to the construction of the cell, I spoke with an engineer at PSI (Professional Service Industries), Inc., Pittsburgh Testing Laboratory

Division. PSI performs permeability tests on samples for their clients. Dr. Cobb, Ms. Clifford, and I visited the facility in Greentree and were given a tour of the geotechnical services lab by the department manager. In doing so we concluded that, though we may be able to successfully construct a permeability cell, we would not have available the master control panel necessary to perform tests accurately. Therefore, the project was tabled until Dr. Cobb could converse with the Civil Engineering Department as to whether the purchase of a master control panel was feasible.

Recently, the Civil and Environmental Engineering Department has purchased a master control panel for use in geotechnical studies. However, the department does not possess the high pressure permeability cells necessary for our studies. I spoke with the faculty about the possibility of using the master control panel if we purchased 
our own high pressure permeability cell and the internals, such as the latex sheaths and clay plates needed to perform the tests. The faculty stated that the equipment is not designed for high pressure testing and that before any tests can be run, a letter promising to replace any equipment damaged by the tests was required.

At this point, my recommendation is to run a trial permeability test, using the available geotechnical equipment, at a lower pressure (100 psi) to check the results. Pending the outcome of this trial, the group may consider the purchase of the equipment needed for the high pressure testing described in the following section. The equipment is expensive and perhaps the results of a trial run at a lower pressure will justify the purchase cost.

\section{RECOMMENDED EQUIPMENT FOR PURCHASE}

The master control panel is capable of measuring pressures up to $300 \mathrm{psi}$. However, the permeability cells can only withstand about 100 psi. In addition, the pressure provided by the in-house air system at Benedum Hall can only produce pressures of $100 \mathrm{psi}$. Therefore, in addition to a high pressure permeability cell (one that can withstand pressures up to about $350 \mathrm{psi}$ ), the group would need to purchase an air booster pump to increase the pressure applicable to the permeability cells, or design some other method for increasing the pressure. As for other necessary equipment, the group must purchase a pore pressure transducer. This device measures the amount of saturation of the sample in the cell and is necessary for accurately measuring the permeability. In addition, 3 inch porous stones and latex membranes are necessary for the operation of the cell. 


\section{APPENDIX C}

A STUDY OF OPTIMIZING THE RECIPES FOR STABILIZATION OF METAL-LADEN WASTES/BY-PRODUCT MIXTURES 


\section{A Study of Optimizing the Recipes for \\ Stabilization of Metal-Laden Waste/By-Product Mixtures}

Submit to: Dr. James T. Cobb, Jr.

Director of Energy Resources Program

From: Guansheng Yin

Energy Resources Program

University of Pittsburgh

August 22, 1996 


\section{Acknowledgments}

As a visiting scholar from Xian Highway University, I have been working in the University of Pittsburgh for two months. During this period, I am participating in research projects, such as making ACC with solid wastes from coal-fired power plants, the treatment of metal-laden hazardous wastes with clean coal technology by-products, and bridge engineering (static and fatigue strength determination of design properties for grid bridge decks). I participated in the following activities: (1) making ACC blocks; (2) making cylinders of mixture of by-product/wastes; (3) fatigue testing of grid bridge decks.

Working with the new colleagues on some new research projects here provides me both challenges and opportunities. More important, participating in the research here gives me an opportunity to know new technology which may be used in China to solve environmental problems. Also, the cooporative programs between Xian Highway University and University of Pittsburgh in education and research will be setup.

I would like to express my grateful appreciation to Dr. James T. Cobb Jr., director of Energy Resources Program, University of Pittsburgh, who financially sponsors my research here. My thanks are extended to Dr. Clark. Mangelsdorf, Ms. Vourneen Clifford, and Mr. Wenyi $\mathrm{Hu}$, for their kind help. 


\section{INTRODUCTION}

Nowadays, the environmental problems are becoming more and more challenging. From the largest developed country, the United States, to the largest developing country, the People's Republic of China, environmental problems are being given more attention. For example, metal-laden hazardous wastes from industrial and military sites have become a very serious problem both in the United States and in China. Since the middle of the 1980s, China has become the fastest developing country, but the environment was not given attention. Luckily,the Chinese government is realizing the environmental problemsit faces. For instance, in July 1996, the government held a national environmental meeting in Beijing, and many laws and regulations have been proposed on how to control the pollution from gas, liquid and solid wastes. I believe that there will be more cooporation between the two countries in the area of environmental engineering.

The metal-laden hazardous wastes, which are produced from the industrial and military sites, create a lot of environmental problems. Dr. Cobb's topical report ( Phase I) provides us with an excellent solution for treatment of the metal-laden hazardous wastes.

Generally, metal-laden hazardous wastes are stabilized by using lime or Portland cement. However, the cost of the process is rather high. The stabilization of metal-laden hazardous wastes with fly-ashes can greatly reduce the costs. In addition, environmental benefication is more significant since the fly-ashes themselves are a type of wastes. The

topical report also indicates further research tasks. The conclusions that were drawn from 
Phase I are very important and useful. The testing results in Phase I are encouraging and are comparable to those obtained by using lime or Portland technology. If future study (Phase II ) can be done on schedule (as I know, most of the work of Phase II has get to be done), many of useful results will be achieved.

I am very interested in this research project because the technique derived from the research is feasible and economical one, which is much needed in China too. As mentioned in the topical report and discussed with Dr. Cobb, Ms. Clifford,Dr.Neufeld, and Mr. Wenyi $\mathrm{Hu}$, the process could be improved significantly in term of stabilization of metals, which could be accomplished in Phase II of the research. As suggested by Dr. Cobb, I have worked on the project, especially on improving the stabilization and mechanical properties of the waste/byproduct concrete. Based on the experimental results obtained from Phase I of the research and my experiences in the cement-concrete technology, I have proposed recipes for waste/byproducts concrete, in order to improve stabilization and compressive strength. 


\subsection{ANALYSIS OF RESULTS OF PHASE I}

\subsection{Role of Calcium Oxide}

From the data of the lead concentration in leachates of the treated wastes listed in Tables $2-13$, it can be found that the stabilization of hazardous wastes is mainly affected by the quantity of calcium oxide $(\mathrm{CaO})$ in the by-product. The higher the amount of calcium oxide the by-product contains, the better the stabilization of the waste/by-product mixture . The data are comparable to those in the case when lime is used to stabilize the leaching of hazardous waste ${ }^{[1]}$. For example, the mean amount of calcium oxide in CONSOL by-product is $28.91 \%$, and that of Tidd (EPC) by-product is $20.94 \%(10.61 \%$ ). This phenomenon can be ascribed to the fact that when a chemical reaction takes place in the mixture, the active calcium oxide plays an important rule in the reaction.

\subsection{The Role of Silica and Alumina}

From the data listed in the table, it can be seen that stabilization is also affected by the ratio of $\mathrm{SiO}_{2} / \mathrm{Al}_{2} \mathrm{O}_{3}$ in the mixture. The lower the ratio of $\mathrm{SiO}_{2} / \mathrm{Al}_{2} \mathrm{O}_{3}$ the mixture has, the better stabilization it shows. Aluminum oxide $\left(\mathrm{Al}_{2} \mathrm{O}_{3}\right)$ is an active geo-chemical but silicon dioxide $\left(\mathrm{SiO}_{2}\right)$ is an inertial one. But for solidification, the higher the ratioof $\mathrm{SiO}_{2} / \mathrm{Al}_{2} \mathrm{O}_{3}$, the higher the compressive strength of the wastes treated ${ }^{\left[{ }^{[2]}\right.}$ Iron oxide $\left(\mathrm{Fe}_{2} \mathrm{O}_{3}\right)$ is an inert geo-chemical, too. That is why the low amount of iron oxide in the by-product is favorable for both stabilization and solidification. The loss on ignition (LOI) plays a similar role, 
especially for solidification, ${ }^{[2]}$ as shown in Table 1 . All the factors have to be kept in balance in order to achieve the optimum results.

\subsection{The Effects of the Physical Properties of By-Product on Stabilization and Solidification}

The stabilization and solidification of the waste and by-product mixture are affected by the physical properties of the waste and by-products, too. The following phenomenon are derived from the results of Phase I of the research.

(1) The more fine the by-product is, the better the results of both stabilization and solidification. ${ }^{[1],[2]}$

(2) The drier the by-product is, the better the results of both stabilization and solidification. $^{[2]}$

(3) The content of water in the mixture must be optimum. It can promote the results of stabilization and solidification and reduce the influence of freezing-thawing, as well as increase the protection from permeating water. ${ }^{[2]}$

(4) After a 90-day curing, the compressive strengths of EPC by-product/wastes mixture are higher than that of most $\mathrm{ACC}^{[1],[3]}$ If the lead concentration can be reduced below the regulation standard, it is obviously a good construction material as road-base.

(5) From Table 2, it is found that the results of most testing are reasonable. The results of compressive strength and Proctor tests are quite good, most of the leachable lead concentrations are to a level below the current regulatory limit of $5 \mathrm{mg} / \mathrm{L}$, but some 
that cannot be understood . E.g, sometimes, the variations of the results lack a regular pattern and appear to be random. Further tests are needed to check the possibilities and get them clear. 


\subsection{SUGGESTION TO THE FUTURE WORK}

\subsection{Stabilization}

As discussed above, the stabilization of the mixture is a function of the quantity of calcium oxide. In order to improve the stabilization of the mixture, the following recipes are proposed.

(1) An optimum amount of lime (less than $8 \%$ of the mixture) or Portland cement (less than 10\%) should be added to the EPC(Tidd) by-product/wastes so that there will be enough calcium oxide in the mixture and to reduce the amount of leaching metals to the regulation level.

(2) From the Table 2-13, it can be found that CONSOL by-product alone can stabilize the leachable metals. Tables show that $10 \%$ of the CONSOL by-product gives us a satisfactory results. The recipe with $15 \%$ CONSOL by-product, and $25 \%$ EPC(Tidd) byproduct, and $60 \%$ hazardous wastes, should give reasonable results for both stabilization and solidification.

The variables in the above recipe can be changed, based on the preliminary testing results. For example, the quantity of the CONSOL by-product can be chosen as $10 \%$ or $20 \%$, depending on the experimental data obtained from the tests. 


\subsection{Solidification}

Solidification is an important parameter too. It is also affected by the chemical components of the waste and by-products. Since glass fibre is a kind of waste, it can be added to the mixture to improve solidification. In addition, some cementitious materials such as clay and polymers are also good for improving the solidification of mixtures of waste/byproduct.

The solidification of the waste/by-product mixture is affected by LOI of by-products, too. ${ }^{[4]}$ A low LOI is good for improving solidification.

Another factor which affects the solidification of the mixture is moisture content. A drying agent can be added to the mixture to reduce the moisture content. By using the drying agent, the properties of the waste/by-product mixture , such as solidification, resistantpermeability, and freezing-thawing resistance can be much improved. ${ }^{[2]}$

Finally, the wet curing condition may affect for solidification. Therefore, an optimum curing condition should be identified.

\subsection{Economical Analysis}

To determine the optimum recipes of the of by-product/waste mixture, the costs of transportation and disposal must be considered. To reduce the cost, the amount of byproduct should be reduced, such that the leachable lead concentrations of the mixture just meets the current regulatory standards, and how to get the lightest weight of the mixture of waste/by-product will also be considered. 


\section{References}

1. J. T. Cobb, Jr., Treatment of Metal-laden Hazardous Wastes with Advanced Clean Coal Technology By-Product (Topical Report). March, 1, 1996

2. The Theory of Concrete, ed. by Chongqing Architectural Engineering Institute, Chinese Architectural Industrial Publication Co., July , 1981

3. W. $\mathrm{Hu}$, The Engineering Properties of ACC Blocks Made Using Fly Ashes. Master Thesis, University of Pittsburgh, 1994.

4. The Theory of Cementitious Materials, ed. by Chongqing Architectural Engineering Institute, Chinese Architectural Industrial Publication Co., June, 1980

Table 1 Chemical Properties of By-Products

\begin{tabular}{c|c|c|c}
\hline \hline Geo-Chemical & Consol & Tidd PFBC & Ebensburg \\
\hline $\mathrm{CaO}(\%)$ & 28.91 & 20.94 & 10.61 \\
\hline $\mathrm{SiO}_{2}(\%)$ & 20.18 & 21.75 & 48.56 \\
\hline $\mathrm{Al}_{2} \mathrm{O}_{3}(\%)$ & 10.24 & 9.39 & 18.45 \\
\hline $\mathrm{SiO}_{2} / \mathrm{Al}_{2} \mathrm{O}_{3}(\%)$ & 1.97 & 2.32 & 2.63 \\
\hline $\mathrm{Fe}_{2} \mathrm{O}_{3}(\%)$ & 6.39 & 10.78 & 6.92 \\
\hline $\mathrm{LOI}(\%)$ & 13.13 & 11.23 & 5.28 \\
\hline \hline
\end{tabular}


Table 2 Battery Sludge + By-Product (immediate TCLP concentrations )

\begin{tabular}{|c|c|c|c|c|c|c|c|c|c|c|c|c|c|c|}
\hline \multirow[b]{2}{*}{ Properties } & \multicolumn{2}{|c|}{ BDA Std $(\mathrm{mg} / \mathrm{L})$} & \multicolumn{4}{|c|}{ Consol } & \multicolumn{4}{|c|}{ Tidd PFBC } & \multicolumn{4}{|c|}{ Ebensburg } \\
\hline & Current & Future & $0 \%$ & $10 \%$ & $30 \%$ & $50 \%$ & $0 \%$ & $10 \%$ & $30 \%$ & $50 \%$ & $0 \%$ & $10 \%$ & $30 \%$ & $50 \%$ \\
\hline Cadmium & 1.0 & 0.19 & 0.19 & 0.11 & 0.10 & 0.10 & .19 & .19 & .15 & .10 & .19 & .15 & .13 & .10 \\
\hline Lead & 5.0 & 0.37 & 20 & 0.14 & 0.28 & 0.19 & 20 & 6.50 & 10.00 & 4.10 & 20 & 7.80 & 46.00 & 13.00 \\
\hline Zinc & -- & 5.3 & 2.9 & -- & -- & -- & 2.9 & - & - & -- & 2.9 & -- & -- & -- \\
\hline
\end{tabular}

N

Table 3 Battery Sludge + By-Product (24-hour TCLP concentrations )

\begin{tabular}{|c|c|c|c|c|c|c|c|c|c|c|c|c|c|c|}
\hline \multirow[b]{2}{*}{ Properties } & \multicolumn{2}{|c|}{ BAD Std $(\mathrm{mg} / \mathrm{L})$} & \multicolumn{4}{|c|}{ Consol } & \multicolumn{4}{|c|}{ Tidd PFBC } & \multicolumn{4}{|c|}{ Ebensburg } \\
\hline & Current & Future & $0 \%$ & $10 \%$ & $30 \%$ & $50 \%$ & $0 \%$ & $10 \%$ & $30 \%$ & $50 \%$ & $0 \%$ & $10 \%$ & $30 \%$ & $50 \%$ \\
\hline Cadmium & 1.0 & 0.19 & 0.19 & 0.10 & 0.10 & 0.10 & .19 & 0.18 & 0.14 & 0.10 & .19 & 0.15 & 0.12 & 0.10 \\
\hline Lead & 5.0 & 0.37 & 20 & 0.15 & 0.21 & 0.21 & 20 & 6.80 & 6.60 & 5.10 & 20 & 15.00 & 11.00 & 26.00 \\
\hline Zinc & -- & 5.3 & 2.9 & - & -- & - & 2.9 & -- & -- & -- & 2.9 & -- & -- & -- \\
\hline
\end{tabular}


Table 4 Munitions soil + By-Product (immediate TCLP concentrations)

\begin{tabular}{|c|c|c|c|c|c|c|c|c|c|c|c|c|c|c|}
\hline \multirow[b]{2}{*}{ Properties } & \multicolumn{2}{|c|}{ BDA Std (mg/L) } & \multicolumn{4}{|c|}{ Consol } & \multicolumn{4}{|c|}{ Tidd PFBC } & \multicolumn{4}{|c|}{ Ebensburg } \\
\hline & Current & Future & $0 \%$ & $10 \%$ & $30 \%$ & $50 \%$ & $0 \%$ & $10 \%$ & $30 \%$ & $50 \%$ & $0 \%$ & $10 \%$ & $30 \%$ & $50 \%$ \\
\hline Cadmium & 1.0 & 0.19 & 0.1 & 0.1 & 0.1 & 0.1 & 0.1 & 0.1 & 0.1 & 0.1 & 0.1 & 0.1 & 0.1 & 0.1 \\
\hline Lead & 5.0 & 0.37 & 26 & 0.37 & 0.41 & 0.28 & 26 & 10.00 & 13.00 & 1.20 & 26 & 34.00 & 17.00 & 5.60 \\
\hline Zinc & -- & 5.3 & 8.2 & 4.3 & 8.00 & 5.3 & 8.2 & 7.10 & 5.20 & 1.00 & 8.2 & 6.10 & 2.60 & 1.80 \\
\hline
\end{tabular}

$\vec{\omega}$

Table 5 Munition soil +By-Product (24-hour TCLP concentrations)

\begin{tabular}{|c|c|c|c|c|c|c|c|c|c|c|c|c|c|c|}
\hline \multirow[b]{2}{*}{ Properties } & \multicolumn{2}{|c|}{ BDA Std (mg/L) } & \multicolumn{4}{|c|}{ Consol } & \multicolumn{4}{|c|}{ Tidd PFBC } & \multicolumn{4}{|c|}{ Ebensburg } \\
\hline & Current & Future & $0 \%$ & $10 \%$ & $30 \%$ & $50 \%$ & $0 \%$ & $10 \%$ & $30 \%$ & $50 \%$ & $0 \%$ & $10 \%$ & $30 \%$ & $50 \%$ \\
\hline Cadmium & 1.0 & 0.19 & 0.1 & 0.1 & 0.1 & 0.1 & 0.1 & 0.1 & 0.1 & 0.1 & 0.1 & 0.1 & 0.1 & 0.1 \\
\hline Lead & 5.0 & 0.37 & 26 & 0.41 & 0.35 & 0.28 & 26 & 16.00 & 23.00 & 0.34 & 26 & 20.00 & 9.10 & 4.3 \\
\hline Zinc & - & 5.3 & 8.2 & 9.90 & 6.7 & 5.10 & 8.2 & 7.70 & 5.00 & 1.0 & 8.2 & 6.70 & 3.30 & 1,80 \\
\hline
\end{tabular}


Table 6 Industrial Soil + By-Product (immediate TCLP concentrations)

\begin{tabular}{|c|c|c|c|c|c|c|c|c|c|c|c|c|c|c|}
\hline \multirow[b]{2}{*}{ Properties } & \multicolumn{2}{|c|}{ BDA Std $(\mathrm{mg} / \mathrm{L})$} & \multicolumn{4}{|c|}{ Consol } & \multicolumn{4}{|c|}{ Tidd PFBC } & \multicolumn{4}{|c|}{ Ebensburg } \\
\hline & Current & Future & $0 \%$ & $10 \%$ & $30 \%$ & $50 \%$ & $0 \%$ & $10 \%$ & $30 \%$ & $50 \%$ & $0 \%$ & $10 \%$ & $30 \%$ & $50 \%$ \\
\hline Cadmium & 1.0 & 0.19 & 0.1 & 0.1 & 0.10 & 0.10 & 0.1 & 0.1 & 0.1 & 0.10 & 0.1 & 0.1 & 0.1 & 0.10 \\
\hline Lead & 5.0 & 0.37 & 80 & 0.54 & 0.54 & 0.37 & 80 & 13.00 & 7.00 & 1.70 & 80 & 17.00 & 17.00 & 0.85 \\
\hline Zinc & - & 5.3 & 17 & 5.20 & 8.3 & 8.4 & 17 & 15.00 & 7.00 & 2.90 & 17 & 10.00 & 5.4 & 1.0 \\
\hline
\end{tabular}

$\$$

Table 7 Industrial Soil + By-Product (24-hour TCLP concentrations )

\begin{tabular}{|c|c|c|c|c|c|c|c|c|c|c|c|c|c|c|}
\hline \multirow[b]{2}{*}{ Properties } & \multicolumn{2}{|c|}{ BDA Std (mg/L) } & \multicolumn{4}{|c|}{ Consol } & \multicolumn{4}{|c|}{ Tidd PFBC } & \multicolumn{4}{|c|}{ Ebensburg } \\
\hline & Current & Future & $0 \%$ & $10 \%$ & $30 \%$ & $50 \%$ & $0 \%$ & $10 \%$ & $30 \%$ & $50 \%$ & $0 \%$ & $10 \%$ & $30 \%$ & $50 \%$ \\
\hline Cadmium & 1.0 & 0.19 & 0.1 & 0.1 & 0.1 & 0.1 & 0.1 & 0.1 & 0.1 & 0.1 & 0.1 & 0.1 & 0.1 & 0.1 \\
\hline Lead & 5.0 & 0.37 & 80 & 0.15 & 0.26 & 0.21 & 80 & 17.00 & 22.00 & 1.60 & 80 & 29.00 & 7.40 & 5.40 \\
\hline Zinc & - & 5.3 & 17 & 8.20 & 9.40 & 13.00 & 17 & 14.00 & 7.60 & 2.40 & 17 & 12.00 & 6.20 & 3.10 \\
\hline
\end{tabular}


Table 8 BOX DUST + By-Product (immediate TCLP concentrations )

\begin{tabular}{|l|l|l|l|l|l|l|l|l|l|l|l|l|l|l|}
\hline & \multicolumn{4}{|l|}{ BDA Std (mg/L) } & \multicolumn{4}{|c|}{ Consol } & \multicolumn{4}{|c|}{ Tidd PFBC } & \multicolumn{4}{|c|}{ Ebensburg } \\
\cline { 2 - 16 } Properties & Current & Future & $0 \%$ & $10 \%$ & $30 \%$ & $50 \%$ & $0 \%$ & $10 \%$ & $30 \%$ & $50 \%$ & $0 \%$ & $10 \%$ & $30 \%$ & $50 \%$ \\
\hline Cadmium & 1.0 & 0.19 & 0.1 & 0.1 & 0.1 & 0.1 & 0.1 & 0.1 & 0.1 & 0.1 & 0.1 & 0.1 & 0.1 & 0.1 \\
\hline Lead & 5.0 & 0.37 & 14 & 1.50 & 5.10 & 6.90 & 14 & 20.00 & 14.00 & 13.00 & 14 & 22.00 & 16.00 & 13.00 \\
\hline Zinc & -- & 5.3 & 4.4 & 4.10 & 3.90 & 3.10 & 4.4 & 4.20 & 4.30 & 4.30 & 4.4 & 4,60 & 4.90 & 4.70 \\
\hline
\end{tabular}

जे

Table 9 BOF DUST + By-Product (24-hour TCLP concentrations )

\begin{tabular}{|c|c|c|c|c|c|c|c|c|c|c|c|c|c|c|}
\hline \multirow[b]{2}{*}{ Properties } & \multicolumn{2}{|c|}{ BDA Std (mg/L) } & \multicolumn{4}{|c|}{ Consol } & \multicolumn{4}{|c|}{ Tidd PFBC } & \multicolumn{4}{|c|}{ Ebensburg } \\
\hline & Current & Future & $0 \%$ & $10 \%$ & $30 \%$ & $50 \%$ & $0 \%$ & $10 \%$ & $30 \%$ & $50 \%$ & $0 \%$ & $10 \%$ & $30 \%$ & $50 \%$ \\
\hline Cadmium & 1.0 & 0.19 & 0.1 & 0.1 & 0.1 & 0.1 & 0.1 & 0.1 & 0.1 & 0.1 & 0.1 & 0.1 & 0.1 & 0.1 \\
\hline Lead & 5.0 & 0.37 & 14 & 17.00 & 9.60 & 4.30 & 14 & 19.00 & 15.00 & 9.60 & 14 & 20.00 & 14.00 & 8.10 \\
\hline Zinc & -- & 5.30 & 4.4 & 3.90 & 3.30 & 2.60 & 4.4 & 3.90 & 3.70 & 3.30 & 4.4 & 4.10 & 3.90 & 3.50 \\
\hline
\end{tabular}


Table 10 Municipal waste DUST + By-Product (immediate TCLP concentrations )

\begin{tabular}{|c|c|c|c|c|c|c|c|c|c|c|c|c|c|c|}
\hline \multirow[b]{2}{*}{ Properties } & \multicolumn{2}{|c|}{ BDA Std $(\mathrm{mg} / \mathrm{L})$} & \multicolumn{4}{|c|}{ Consol } & \multicolumn{4}{|c|}{ Tidd PFBC } & \multicolumn{4}{|c|}{ Ebensburg } \\
\hline & Current & Future & $0 \%$ & $10 \%$ & $30 \%$ & $50 \%$ & $0 \%$ & $10 \%$ & $30 \%$ & $50 \%$ & $0 \%$ & $10 \%$ & $30 \%$ & $50 \%$ \\
\hline Cadmium & 1.0 & 0.19 & 0.1 & 22.00 & 13.00 & 8.00 & 0.1 & 25.00 & 18.00 & 14.00 & 0.1 & 22.00 & 18.00 & 15.00 \\
\hline Lead & 5.0 & 0.37 & 20 & 1.30 & 0.46 & 0.26 & 20 & 16.00 & 17.00 & 9.10 & 20 & 12.00 & 20.00 & 13.00 \\
\hline Zinc & -- & 5.3 & 2.1 & 740.0 & 410.0 & 310.0 & 2.1 & 550.0 & 400.0 & 280.0 & 2.1 & 530.0 & 500.0 & 370.0 \\
\hline
\end{tabular}

के

Table 11 Municipal Waste DUST + By-Product ( 24-hour TCLP concentrations )

\begin{tabular}{|l|l|l|l|l|l|l|l|l|l|l|l|l|l|l|}
\hline & \multicolumn{9}{|c|}{ BDA Std (mg/L) } & \multicolumn{4}{|c|}{ Consol } & \multicolumn{4}{c|}{ Tidd PFBC } & \multicolumn{4}{c|}{ Ebensburg } \\
\cline { 2 - 15 } Properties & Current & Future & $0 \%$ & $10 \%$ & $30 \%$ & $50 \%$ & $0 \%$ & $10 \%$ & $30 \%$ & $50 \%$ & $0 \%$ & $10 \%$ & $30 \%$ & $50 \%$ \\
\hline Cadmium & 1.0 & 0.19 & 0.1 & 24.00 & 14.00 & 9.0 & 0.1 & 30.00 & 17.00 & 13.00 & 0.1 & 20.00 & 17.00 & 14.00 \\
\hline Lead & 5.0 & 0.37 & 20 & 1.60 & 0.45 & 0.27 & 20 & 13.00 & 16.00 & 12.00 & 20 & 22.00 & 22.00 & 24.00 \\
\hline Zinc & -- & 5.3 & 2.1 & 650.0 & 330.0 & 280.0 & 2.1 & 700.0 & 370.0 & 270.0 & 2.1 & 500.0 & 420.0 & 300.0 \\
\hline
\end{tabular}


Table 12 Sewage Soil + By Product (immediate TCLP concentrations )

\begin{tabular}{|c|c|c|c|c|c|c|c|c|c|c|c|c|c|c|}
\hline \multirow[b]{2}{*}{ Properties } & \multicolumn{2}{|c|}{ BDA Std (mg/L) } & \multicolumn{4}{|c|}{ Consol } & \multicolumn{4}{|c|}{ Tidd PFBC } & \multicolumn{4}{|c|}{ Ebensburg } \\
\hline & Current & Future & $0 \%$ & $10 \%$ & $30 \%$ & $50 \%$ & $0 \%$ & $10 \%$ & $30 \%$ & $50 \%$ & $0 \%$ & $10 \%$ & $30 \%$ & $50 \%$ \\
\hline Cadmium & 1.0 & 0.19 & 0.1 & 0.1 & 0.1 & 0.1 & 0.1 & 0.1 & 0.1 & 0.1 & 0.1 & 0.1 & 0.1 & 0.1 \\
\hline Lead & 5.0 & 0.37 & 7.8 & 0.39 & 0.57 & 0.46 & 7.8. & 21.00 & 9.40 & 2.30 & 7.8 & 4.90 & 4.60 & 0.31 \\
\hline Zinc & -- & 5.3 & 3.9 & 2.10 & 4.70 & 1.70 & 3.9 & 4.30 & 2.10 & $<1$ & 3.9 & 2.30 & $<1$ & $<1$ \\
\hline
\end{tabular}

$\pm$

Table 13 Sewage Soil + By-Product (24-hour TCLP concentrations )

\begin{tabular}{|c|c|c|c|c|c|c|c|c|c|c|c|c|c|c|}
\hline \multirow[b]{2}{*}{ Properties } & \multicolumn{2}{|c|}{ BDA Std $(\mathrm{mg} / \mathrm{L})$} & \multicolumn{4}{|c|}{ Consol } & \multicolumn{4}{|c|}{ Tidd PFBC } & \multicolumn{4}{|c|}{ Ebensburg } \\
\hline & Current & Future & $0 \%$ & $10 \%$ & $30 \%$ & $50 \%$ & $0 \%$ & $10 \%$ & $30 \%$ & $50 \%$ & $0 \%$ & $10 \%$ & $30 \%$ & $50 \%$ \\
\hline Cadmium & 1.0 & 0.19 & 0.1 & 0.1 & 0.1 & 0.1 & 0.1 & 0.1 & 0.1 & 0.1 & 0.1 & 0.1 & 0.1 & 0.1 \\
\hline Lead & 5.0 & 0.37 & 7.8 & 0.47 & 0.56 & 0.55 & 7.8 & 23.00 & 11.00 & 2.10 & 7.8 & 11.00 & 0.1 .0 & 0.18 \\
\hline Zinc & - & 5.3 & 3.9 & 2.30 & 2.90 & 1.90 & 3.9 & 7.8 & 2.90 & 1.00 & 3.9 & 2.00 & $<1$ & $<1$ \\
\hline
\end{tabular}




\section{APPENDIX D}

\section{EXCHANGE OF LETTERS BETWEEN ENVIRITE CORPORATION}

AND THE UNIVERSITY OF PITTSBURGH ON PHASE 2 


\section{University of Pittsburgh}

SCHOOL OF ENGINEERINC

Center for Energy Research

July 1,1996

Mr. Richard Kostelnick

Regional General Manager

Envirite Corporation

2050 Central Avenue SE

Canton, $\mathrm{OH} 44707$

Dear Mr. Kostelnick:

I very much appreciated our telephone conversation on Friday, June 21, about the possibility of Envirite joining our project on "Treatment of Metal-Laden Hazardous Wastes with Advanced Clean Coal Technology By-Products. We here at Pitt are hopeful that a successful negotiation can be conducted over the next few weeks.

Carl Bender, the project manager for Phase One at Mill Service, Inc., and currently our industrial consultant on Phase Two, has given you some background on the program and I was pleased to add additional information in our discussion last week. In that conversation you mentioned the permit application you are pursuing and your need to avoid any activity that would jeopardize its successful conclusion which is expected soon - at the latest in October. We understand and appreciate your position on this, having experienced Mill Service's sensitivities in a much more exposed situation.

As I promised, l've made copies of the topical report, which describes the first year's laboratory work on the project, and the continuation application, which we submitted about this time a year ago to obtain the funding for Phase Two. The second document is a comprehensive description of the goals and basic approach of the commercial test we wish to provide of the technology. It is essentially a straightforward application of the new treatment chemicals advanced clean coal by-products - to characteristic metal-laden hazardous wastes that are regularly processed at your facility. I would anticipate that you would do bench-scale treatability studies in your laboratory to validate effective treatment recipes and then carry out commercial-scale treatments in your plant.

I have also made a copy of the contract between Pitt and Mill Service. I would expect one with Envirite to be similar. I will send all three documents by overnight mail today. You should receive them tomorrow.

Let me return now to the principal concern we all have about the possibility of our sponsor, the Morgantown Energy Technology Center (METC) of the U.S. Department of Energy, requiring an environmental assessment (EA), including public notification, comment and hearings (if requested). Scott Renninger, our Contracting Officer's Representative at METC, 
Mr. Richard Kostelnick

July 1, 1996

Page Two

on Friday informed me that the METC environmental staff may by able to provide a categorical exclusion $(C X)$ by the end of this week if they can receive a completed NEPA Checklist for Phase Two by this afternoon. He sent me a copy of the blank form and I have tentatively completed it as it would be if Envirite and your plant were our partner. It is attached to this letter being FAXed to you. The checklist I send to METC, hopefully later today, will clearly be labeled as a draft, subject to successful negotiation of a contract between Pitt and Envirite. If we can be granted a $\mathrm{CX}$ at this juncture, then we can proceed without the requirement for an EA. It would be very helpful and much appreciated if you could take a moment at your very earliest convenience this morning to look over this simple form and then call me with your comments as soon thereafter as possible.

After you've had an opportunity to review the three reports that will arrive tomorrow, let's plan to discuss them further, explore areas of mutual interest, and identify specific ways in which we can work together on this project. It may prove helpful for me to come over to Canton, perhaps when Carl can come through also, to do this. Please give me another call when you are ready for this discussion.

Sincerely,

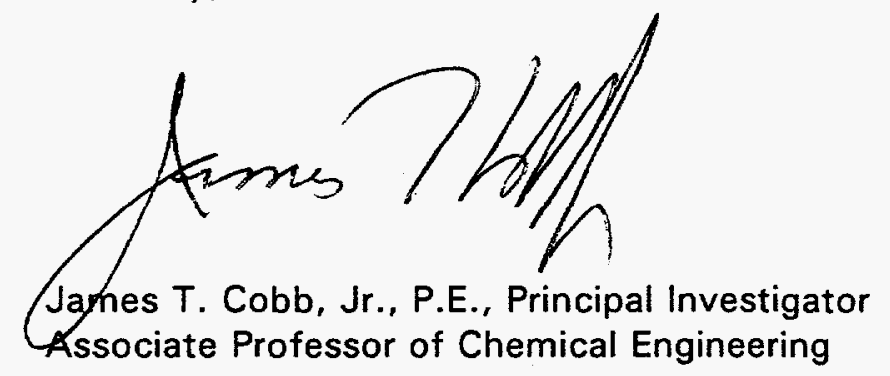

cc. Ronald Neufeld

Carl Bender

Scott Renninger 


\section{NEPA CHECKLUST}

1. Date: July 1, 1996

NEPA \#. $\longleftrightarrow\langle N \gg$

2. Activity/Project Tille--Contract: Treatment of Metal-Laden Hazardous Wastes with Advanced Clean Coal Technology By-Products

3. Project Mrager/Division: Scott Renninger

4. Project/Activity Description:

Commercial treatment of up to ten 20-ton lots of solid characteristic metal-laden hazardous wastes with up to 10 toms per lot of up to three different advanced clean coal technology byproducts - residue from a spray drier absorber, residue from a coal-waste-fired circulating fluidbed combustor and residue from a coal-fired pressurized fluid-bed combustor - at a fullypermitted commercial hazardous waste treatment plant.

5. Brief Description of Affected Environment:

The commercial treatment will be performed at the Canton, Ohio plant of Envirite Corporation. The stabilized product will be disposed to the non-hazardous industrial waste landfill used regularly by Envirite.

6. Environmental Concerns: Would the project/activity, either during construction or operation, result in changes or disturbances to the following entities! Provide brief explanations to any "yes" answers on an attached page.

6.1 Threaten a violation of applicable stalutory, regulatory, or permit requirements for environmeat, safety, and health requirements of DOE orders?

YES NO $X$ UNKNOWN

6.2 Siting and construction or major expansion of wastc storage, disposal recovery, or treatment facilities?

YES - NO X UNKNOWN

6.3 Uncontrolled or unpermilted relcases resulting from hazardous substances, pollutants or CERCLA-excluded petroleum and natural gas products that preexist in the environment?

YES NO $x$ UNXNOWN

DRAFT - subject to successful negotiation between Envirite and U. Pittsburgh 
6.4 Adversely affect environmentally sensitive resources, including:
a) Threatened/Eodangered Species or Critical Habitat Areas
YES NO $X$ UNKNOWN
b) Flood Plains/Wetlands
YES
NO $\mathrm{X}$ UNKNOWN
c) Archacological/Cultural Resources
YES _ NO $X$ UNKNOWN
YTS
NO $\mathrm{X}$ UNKNOWN
d) Prime. Unique or Important Farmland
YES
NO $X$ URTNOWN
e) Special sources of Groundwatcr (sole source aquifer, etc.)
f) Tundra, Coral Reefs, Rain Forests, Coastal Zunes
YES NO $x$ UNKNOWN
YES NO $\triangle$ UNKNOWN
h) National Parks, Wild and Scenic Rivers, Waters of the State, etc.

6.5 Emil any of the Clean Air Act Criteria Pollutants (sulfur dioxide, nitrogen oxides, carbon monoxide, ozonc, particulates ( $\left(\mathrm{M}_{10}\right)$ leud, volatile organic compounds (VOCs))?

YES NO $X$ UNKNOWN

7. ADDITIONAL INFORMATION (Provide brief explanations of any "YES" answers on an attached sheet.) Would the project/activity ...

7.1 Affect water use and quality, including sedimenlation, and discharge of point/nonpoint source pollutants to surface or groundwater? YIS _ NO $\perp$ UNKNOWN

7.2 Control or modify the watcrs, streambed, or shoreline of any stream ur watce body'? YES NO $X$ UNKNOWN

7.3 Result in the generation, transportation, and disposal of any hazardous or toxic materials as defined by Fedcral or applicable state regulations?

YES NO $x$ UNRKOWN

7.4 Affect any aspect of the human environment besides those mentioned above either directly or indirectly (e.g., visibility, noise, desthetic and socioeconomic impacts; public facilities and services or exposure to toxic and hazardous material)?

7.5 Generate public controversy? YES _ NO X UNKNOWN

7.6 Cumulative Impacts: None

7.7 Pollution Prevention: A currently Beville waste (advanced clean coal technology byproduct) will be utilized as a potential product of comerce.

DRAFT - subject to successfuI negotiation between Envirite and $U$. Pittsburgh 


\section{EnVIRITE CORPORatIOn}

TECHNOLOGY FOR THE ENVIRONMENT

Richard J. Kostelnick

Envirite Corporation

2050 Central Ave SE

Canton, Ohio 44707

Dr. James Cobb

University of Pittsburgh

350 Thackeray Hall

Pittsburgh, Pennsylvania 15260

July 10,1996

Dear Dr. Cobb:

Enclosed you will find the returned information provided to Envirite concerning the proposed metals treatment project. I regret that we can not participate in your project at the present time.

Thank you for your interest in Envirite.

Sincerely,

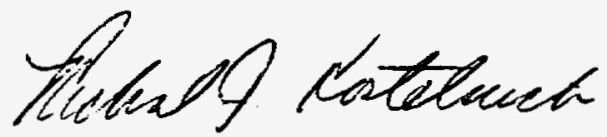

Richard J. Kostelnick

Regional General Manager, Envirite Corporation 
APPENDIX E

PROGRAM FOR THE RESEARCH EXPERIENCE FOR UNDERGRADUATES SUMMER RESEARCH SYMPOSIUM 


\title{
RESEARCH EXPERIENCE FOR UNDERGRADUATES
}

\section{SUMMER RESEARCH SYMPOSIUM}

\author{
Wednesday, August 7, 1996 \\ 1175 Benedum Hall (Kresge Conference Room) \\ sponsored by: \\ Natinnal Scienco Foundation \\ and \\ The Department of Chemical and Petroleum Engineering \\ University of Pittsburgh
}

\section{8:45 a.m.}

9:00 a.m.

Scientific Program:

9:15 a.m. Donna Person

9:30 a.m. Ian Conner

9:45 a.m. Sarah Spencer

10:00 a.m. Ann Crowther
Coffee and Doughnuts

Welcome Dr. Mohammad Ataai, REU Program Director Dept. of Chemical and Petroleum Engineering

Dr. Alan Russell, Professor and Chairman

Dept. of Chemical and Petroleum Engineering

\section{PROGRAM}


10:15 a.m. Tom Holden

10:30 a.m. Coffee Break

10:45 a.m. David Craig

11:00 a.m. John Downs

11:15 a.m. Ryan Miller

11:30 a.m. Jaya Ramathal

11:45 a.m. Amanda Lydic

12:00 noon Lunch

1:00 Mary Bedner

1:15 p.m. Jesús López

1:30 p.m. Neal Yakelis

1:45 p.m. Dana Hall

2:00 p.m. David P. White Jr.
"DSC Measurements of Polystyrene"

"Copolymerization of Carbon Dioxide and 1,4 Cyclohexadiene"

"The Role of Shear Stress in the Formation of Subaortic Stenosis"

"A Fiber Optic Probe for Imaging Cellular Deposition"

"Effect of Fluid Viscosity and Carrier Frequency on the Persistence of Echocardiographic Contrast Agents Exposed to Various Transmit Powers"

"Development of Enzyme Assay Quantification of Surface Bound Polyethyleneglycol"

"The Effects of Exposure to Liquid Carbon Dioxide on PostConsumer Plastics During Microsortation."

"Polymer Synthesis Using Enzyme Catalysts"

"Synthetic Utility of the Ethynyl Functionality in $\mathrm{Cl}(\mathrm{dmpe})_{2} \mathrm{WC} \mathrm{C}_{6} \mathrm{H}_{4}-\mathrm{CCH}^{\prime \prime}$

"Synthesis of ${ }^{13} \mathrm{C}$ Labeled Mesityl Oxide for Acidity Measurement"

"Measurement of Acid Strength of a Paraffin Alkylation Catalyst" 